\title{
Recovery of a foreign protein from the periplasm of Escherichia coli by chemical permeabilization
}

\author{
Thomas J. Naglak and Henry Y. Wang \\ Department of Chemical Engineering, University of Michigan, Ann Arbor, Michigan, \\ $U S A$
}

\begin{abstract}
We have applied the technique of protein release by chemical permeabilization to recover a foreign protein in active form from the periplasm of a recombinant strain of Escherichia coli. The two agents used in our chemical permeabilization scheme, guanidine hydrochloride and Triton X-100, have different modes of action, allowing selectivity in protein release based on intracellular location under different treatment conditions. Specifically, treatment of E.coli C600-1 cells by guanidine alone resulted in 40fold purification of recombinant $\beta$-lactamase, which is periplasmically expressed in this host. Achieving such high purification in the cell disruption stage could alleviate some of the problems associated with recovery of intracellular products, such as low expression or the need to solubilize cytoplasmic inclusion bodies. Recovery of periplasmic proteins by chemical permeabilization is simpler than by osmotic shock and is less expensive than using enzymatic digestion.
\end{abstract}

Keywords: $\beta$-Lactamase; cell disruption; chemical permeabilization; Escherichia coli; periplasmic proteins; protein recovery

\begin{abstract}
Introduction
Despite myriad advances in genetic engineering, recombinant DNA technology has yet to provide a systematic approach for consistently inducing microorganisms to secrete foreign proteins extracellularly. This problem is particularly acute in the case of Escherichia coli, a popular host system which does not secrete any of its native proteins. However, many E. coli proteins are found in the periplasmic space, indicating translocation past the inner membrane, but not past the outer membrane. Recently, several researchers ${ }^{1-6}$ have successfully induced $E$. coli to secrete to the periplasmic space foreign proteins produced in the cytoplasm using foreign or native signal sequences.

Traditional methods for recovering periplasmic proteins from $E$. coli typically involve either disruption of the outer membrane by osmotic shock ${ }^{7,8}$ or digestion of the peptidoglycan layer by lysozyme in the presence of EDTA. ${ }^{9,10}$ However, the former method requires several additional centrifugation and resuspension
\end{abstract}

Address reprint requests to Dr. Wang at the Department of Chemical Engineering, The University of Michigan, Ann Arbor, MI 48109-2136

Received 25 May 1989; revised 11 August 1989 steps in processing, and the latter method entails added expense in providing the enzyme lysozyme.

Previous work in our laboratory ${ }^{11}$ has demonstrated the feasibility of releasing $E$. coli proteins through chemical permeabilization. Specifically, it was shown that certain combinations of guanidine and Triton X100 release significant amounts of intracellular protein from a native strain of $E$. coli. Advantages over mechanical disruption, the current industrial method of attaining protein release, include avoiding cell fragmentation and limited release of nucleic acids under certain treatment conditions. The goals of the present work are to extend the concept of chemical permeabilization to recovery of a foreign protein in active form from a recombinant strain of $E$. coli and to demonstrate the potential for achieving selectivity in protein release based on intracellular location.

The two treatment agents in this chemical permeabilization scheme have different modes of action. Guanidine is a chaotropic agent capable of solubilizing some normally hydrophobic compounds, perhaps due to its interactions with the hydrogen bonding of water. ${ }^{12,13}$ Specifically, guanidine has been shown to solubilize protein from $E$. coli membrane fragments. ${ }^{14}$ Triton X100 is a nonionic detergent known for its ability to solubilize phospholipid bilayer membranes. ${ }^{15}$ Triton X100 has been shown to solubilize proteins from the 
cytoplasmic membrane portion of $E$. coli cell wall fragments, but not from the outer membrane portion. ${ }^{16}$ This is consistent with the general observation that detergents affect only the inner membrane of Gramnegative bacteria, the lipopolysaccharides of the outer membrane providing resistance to detergents. ${ }^{17}$ Electron microscopy studies in our laboratory ${ }^{18}$ have shown that guanidine's role in the chemical permeabilization process may be to disrupt the outer membrane, exposing the inner membrane to attack by Triton X-100. Thus, it was anticipated that selectivity in recovering proteins from the periplasm could be achieved under specific treatment conditions, namely, treatment with guanidine alone.

\section{Materials and methods}

\section{Bacterial strain and culture conditions}

Escherichia coli C600-1, genetically engineered to produce $\beta$-lactamase from Bacillus licheniformis, ${ }^{19}$ was maintained at $-20^{\circ} \mathrm{C}$ in $50 \%$ glycerol. Inoculum shake flask cultures were grown in modified L-broth (MLB) at $37^{\circ} \mathrm{C}$ with constant shaking. MLB contains, per liter distilled water, $10 \mathrm{~g}$ yeast extract, $20 \mathrm{~g}$ tryptone, $0.5 \mathrm{~g}$ $\mathrm{NaCl}$, and $5 \mathrm{~g}$ cerelose. The $\mathrm{pH}$ was adjusted to 7.0 prior to autoclaving, and filter sterilized tetracycline was added to $20 \mu \mathrm{g} \mathrm{ml}^{-1}$ after autoclaving. Bulk cell mass was grown by inoculating 11 of a $12-\mathrm{h}$ culture in MLB to 91 of defined medium, ${ }^{11}$ supplemented with 20 $\mu \mathrm{g} \mathrm{ml}^{-1}$ tetracycline, in a $14-1$ fermentor. The temperature was maintained at $37^{\circ} \mathrm{C}$. The $\mathrm{pH}$ was maintained at 7.0 by addition of $\mathrm{NH}_{4} \mathrm{OH}$. Excess foaming was prevented by periodic addition of Antifoam A. Cell growth was monitored by measuring turbidity, and cells were harvested in late exponential phase and immediately cooled to $4^{\circ} \mathrm{C}$.

\section{Chemical permeabilization}

Cells were recovered from fermentation broth by centrifuging at $4^{\circ} \mathrm{C}$ and washed once in cold treatment buffer $(0.05 \mathrm{~m}$ phosphate, $\mathrm{pH} 7)$. Cells resuspended in treatment buffer were then added to flasks containing similarly buffered cold solutions of guanidine hydrochloride and/or Triton X-100 to yield final solutions with the indicated concentrations of treatment chemicals. The control consisted of resuspended cells added to treatment buffer. The flasks were left gently shaking at $4^{\circ} \mathrm{C}$. Samples were withdrawn at the indicated intervals, centrifuged, decanted, and saved at $4^{\circ} \mathrm{C}$ for later assay. Total cellular protein concentrations, based on final treatment volumes, ranged from approximately 4 to $12 \mathrm{~g} \mathrm{l}^{-1}$, and no variation in recovery results was observed over this range.

\section{Protein assay}

Protein was determined by the method of Bradford ${ }^{20}$ using bovine serum albumin as the standard. Interference by Triton X-100 was accounted for by ensuring that all samples and standards had identical Triton $\mathrm{X}$ -
100 concentrations of $0.2 \%$ or less. Total cellular protein was determined by lysing the cells in $1 \mathrm{~m} \mathrm{NaOH}$ at $100^{\circ} \mathrm{C}$ for $7 \mathrm{~min}$. Standards for the determination of total cellular protein were also exposed to the hot alkali treatment. Protein release is reported as the percentage of protein found in the supernatant based on separate supernatant and total cellular protein assays and employing a gravimetrically determined correction factor for the volume of the pellet. Reported results are based on at least two determinations, and the standard deviation was $3.5 \%$.

\section{$\beta$-Lactamase assay}

$\beta$-Lactamase activity was determined by application of the fixed time method of Sargent. ${ }^{21}$ A $0.1-\mathrm{ml}$ sample was added to $0.4 \mathrm{ml}$ assay buffer $(0.05 \mathrm{M}$ phosphate, $\mathrm{pH} \mathrm{7)} \mathrm{at} \mathrm{room} \mathrm{temperature.} \mathrm{The} \mathrm{reaction} \mathrm{was} \mathrm{initiated}$ by adding $0.1 \mathrm{ml}$ benzylpenicillin $\left(4 \mathrm{mg} \mathrm{ml}^{-1}\right.$ of the potassium salt in assay buffer). After incubation at room temperature for a specified time, the reaction was halted by adding $1 \mathrm{ml}$ iodine reagent. The iodine reagent was prepared as follows: stock solution $\left(20.3 \mathrm{~g} \mathrm{I}_{2}, 100\right.$ $\mathrm{g} \mathrm{KI}$, in $500 \mathrm{ml} \mathrm{dH_{2 }} \mathrm{O}$ ) was diluted $20: 1$ immediately prior to use in acetate buffer ( $40 \mathrm{~g}$ sodium acetate in $\mathrm{dH}_{2} \mathrm{O}$ with glacial acetic acid as necessary to make $1 \mathrm{l}$ final buffer, $\mathrm{pH} 4.0$ ). Within minutes of quenching, the absorbance was read at $540 \mathrm{~nm}$. Included for each assay was a buffer blank or a Triton X-100 blank (buffer containing a Triton X-100 concentration identical to the sample). Enzyme activity is defined as

$$
\frac{\mathrm{A}_{540}(\text { blank })-\mathrm{A}_{540}(\text { sample })}{\text { incubation time }}
$$

Incubation times and sample dilutions (in assay buffer) were adjusted to maintain linearity in the assay. Triton $\mathrm{X}-100$ concentrations in samples were diluted to $0.006 \%$ or less. Reported results are based on at least two determinations, and the standard deviation was $6.9 \%$.

\section{Glucose 6-phosphate dehydrogenase assay}

G6PDH activity was determined spectrophotometrically. ${ }^{22}$ To $1.35 \mathrm{ml}$ room temperature assay buffer $\left(0.055 \mathrm{M}\right.$ Tris, $\left.0.033 \mathrm{M} \mathrm{MgCl}_{2}, \mathrm{pH} 7.8\right)$ was added 0.05 $\mathrm{ml}$ D-glucose 6-phosphate $\left(0.028 \mathrm{mg} \mathrm{ml}^{-1}\right)$ and $0.05 \mathrm{ml}$ $\beta$-NADP $\left(0.0052 \mathrm{mg} \mathrm{ml}^{-1}\right)$. The reaction was initiated by adding $0.05 \mathrm{ml}$ cold sample and the increase in absorbance at $340 \mathrm{~nm}$ recorded for $5 \mathrm{~min}$. Activity is defined by the slope of the absorbance versus time data. When necessary to maintain linearity, samples were diluted with treatment buffer containing guanidine and Triton X-100 concentrations matching the sample. Reported results are based on at least two determinations, and the standard deviation was $3.5 \%$.

\section{Sonication}

Whole broth $\beta$-lactamase and G6PDH concentrations for each treatment were determined by releasing intracellular protein by sonication. One-hundred-microliter 
aliquots were disrupted using the microtip of a Fisher Sonic Dismembrator Model 300 in four discrete 5-s bursts at $35 \%$ power. Between sonication bursts, samples were cooled on ice. After sonication, samples were centrifuged for $30 \mathrm{~min}$ at $15,000 \mathrm{~g}$ and the supernatants were assayed for enzyme activity. For permeabilization treatments, enzyme release is reported as the percentage of activity found in the treatment supernatant compared to that found in the sonication supernatant employing the same pellet volume correction as for protein release.

\section{Preparation of periplasmic extract and whole cell extract}

Periplasmic proteins were purified by lysozyme/EDTA treatment. ${ }^{23}$ Control cells were centrifuged and resuspended in $20 \%$ sucrose to approximately their original volume. After $1 \mathrm{~h}$ at $4^{\circ} \mathrm{C}, 9 \mathrm{ml}$ of this suspension was added to $1 \mathrm{ml} 1 \mathrm{M}$ Tris ( $\mathrm{pH} 7.8$ ). To this was added 0.3 $\mathrm{ml}$ lysozyme $(0.25 \%$ in $0.1 \mathrm{M}$ Tris, $0.2 \mathrm{M} \mathrm{NaCl}, \mathrm{pH} 7.8)$ and $0.86 \mathrm{ml} 0.1 \mathrm{M}$ Tris, 0.1 M EDTA (pH 7.8). The suspension was incubated at $30^{\circ} \mathrm{C}$ for $90 \mathrm{~min}$ with gentle shaking. The spheroplasts were removed by centrifugation, leaving the periplasmic fraction in the supernatant.

Whole cell protein extracts were prepared by sonicating control cells in sonication buffer $(0.01 \mathrm{M}$ Tris, $0.005 \mathrm{M} \mathrm{MgCl}_{2}, \mathrm{pH}$ 7.4) as described under Sonication.

\section{Electrophoresis sample preparation}

Samples for 2D PAGE were prepared from treatment supernatant samples and whole cell and periplasm extract supernatants essentially as described by Phillips. ${ }^{24}$ Three hundred micrograms total protein was precipitated with cold $10 \%$ TCA, resuspended in $150 \mu \mathrm{l}$ sonication buffer, and incubated on ice for $10 \mathrm{~min}$ with $3 \mu \mathrm{l}$ DNase/RNase $\left(2 \mathrm{mg} \mathrm{ml}^{-1}\right.$ each in $\left.0.85 \% \mathrm{NaCl}\right)$. One hundred milligrams urea was added, followed by $300 \mu \mathrm{l}$ lysis buffer ${ }^{24}$ and $22.5 \mu$ l phenylmethylsulfonyl fluoride (100 $\mathrm{mm}$ in anhydrous isopropyl alcohol). Samples were stored at $-20^{\circ} \mathrm{C}$ until electrophoresis.

\section{Electrophoresis conditions}

2D gels were run as described by Phillips. ${ }^{24}$ LKB ampholines were mixed $80 \%$ pH 5-7 and $20 \%$ pH 3.5-10 in

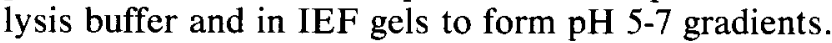
A $30-\mu \mathrm{l}$ sample (approximately $15 \mu \mathrm{g}$ protein) was loaded on each IEF gel and focused at $400 \mathrm{~V}$ for $14 \mathrm{~h}$, followed by $1,000 \mathrm{~V}$ for $1 \mathrm{~h}$. IEF gels were equilibrated for $30 \mathrm{~min}$ in SDS sample buffer ${ }^{24}$ before loading onto second-dimension slab gels, which were run at $25 \mathrm{~mA}$ per gel. Gels were silver stained as described by Damerval and coworkers, ${ }^{25}$ with the following modifications: all solutions were room temperature, the Farmer's Reducer soak was increased to $3 \mathrm{~min}$, and the third developer soak was eliminated. Gels were soaked for $30 \mathrm{~min}$ in $1 \%$ acetic acid, $1 \%$ glycerol, and then stored in this solution.

\section{Image analysis}

Individual protein spots on 2D gels were quantified using an IBM PC based image analysis system and Image Measure 3.04 (Microscience, Inc.). Data acquisition was from video images of wet gels obtained with a Javelin Model 2064IR camera (Javelin) and digitized for an IBM PC-AT using a PFG-8-3 board (Imaging Technology). Quantification is based on integrated optical density (IOD) of a spot using a threshold set halfway between the background intensity and the minimum intensity (i.e. maximum density) for the spot. Pixels with a density lower than this threshold were not included in the measurement, allowing systematic definition of a spot independent of background variations, either local or gel-to-gel. ${ }^{26}$ Under these conditions of electrophoresis, staining, and image analysis, IOD varies linearly with protein amount loaded. ${ }^{26}$ IOD is expressed in arbitrary units; it has dimensions of (Area) $\times$ (Optical Density).

\section{Chemicals}

Guanidine hydrochloride (practical grade), Triton X100, Antifoam A, tetracycline, Coomassie Brilliant Blue G, bovine serum albumin, D-glucose 6-phosphate, $\beta$-NADP, lysozyme, DNase, RNase, and phenylmethylsulfonyl fluoride were from Sigma. Yeast extract and tryptone were from Difco, and cerelose was from DSM Foods. Farmer's Reducer was from Kodak. Ampholytes for electrophoresis were LKB Ampholines.

\section{Results}

\section{Recovery of overall intracellular protein} from recombinant $\mathrm{E}$. coli

The recombinant strain studied was $E$. coli C600-1, genetically engineered to produce $\beta$-lactamase from Bacillus licheniformis. ${ }^{19}$ Overall protein release from this strain by treatment with guanidine and Triton $X$ 100 is similar, but not exactly identical, to protein release observed for the native strain $E$. coli $\mathrm{K} 12$, W3110. ${ }^{11}$ Both strains exhibit an unusual, wave-like response to variations in guanidine concentration at constant $0.5 \%$ Triton $\mathrm{X}-100$, as shown in Figure 1. A significant percentage of overall protein is extracted from either strain in the presence of high concentrations of guanidine (above about $2 \mathrm{M}$ ) combined with $0.5 \%$ Triton $\mathrm{X}-100$. However, there also exists a range of low guanidine concentrations, near $0.1-0.4 \mathrm{M}$ and varying slightly for the two strains, capable of releasing approximately $50 \%$ overall protein when applied in conjunction with $0.5 \%$ Triton $\mathrm{X}-100$.

Further studies with the recombinant strain were conducted using combinations of $0.2 \mathrm{M}$ guanidine and/ or $0.5 \%$ Triton X-100. Figure 2 shows overall protein release under such conditions as a function of time. As observed with the native strain, ${ }^{11}$ neither of these chemicals alone at the given concentration extracts more than about $10 \%$ of intracellular protein. Together, 


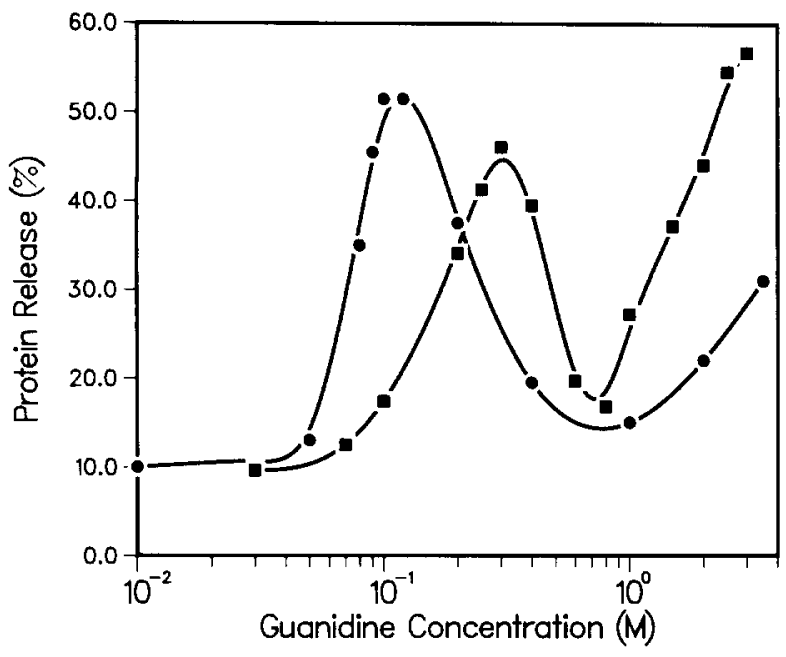

Figure 1 Overall protein release from native $E$. coli $\mathrm{K} 12, \mathrm{~W} 3110$ (C) and from recombinant $E$. coli $\mathrm{C} 600-1$ ( $\square$ ) by chemical permeabilization as a function of guanidine concentration at constant $0.5 \%$ Triton $X-100$. Release data shown for the recombinant strain is for a 24-h treatment. Data for the native strain are from Hettwer and Wang ${ }^{11}$

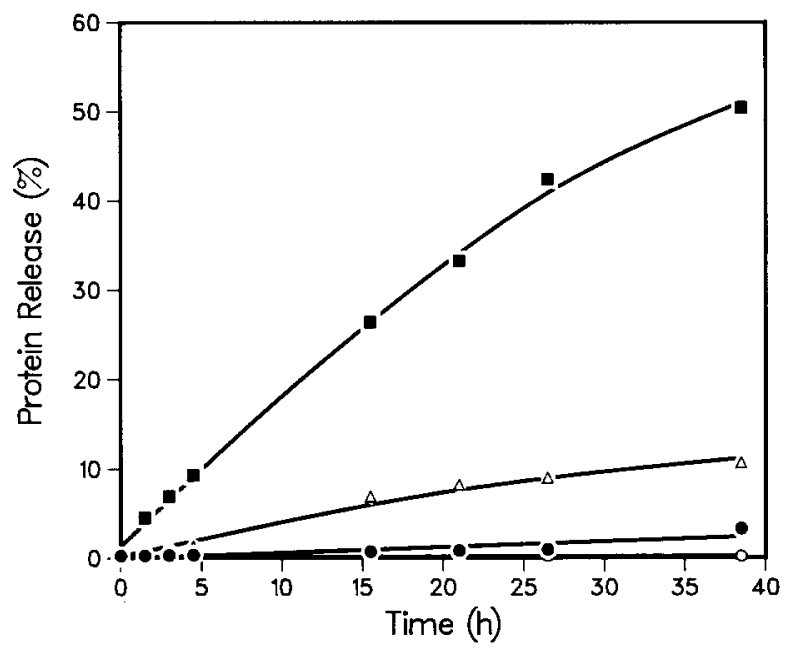

Figure 2 Overall protein release as a function of time for chemical permeabilization of $E$. coli $\mathrm{C} 600-1$ by $0.2 \mathrm{M}$ guanidine (O), $0.5 \%$ Triton $X-100(\Delta)$, and $0.2 \mathrm{~m}$ guanidine plus Triton $X-100$ (E). The control treatment $(O)$ releases less than $1 \%$ protein

however, they exert a synergistic effect, releasing about $50 \%$ overall protein, much more than the sum of their individual effects. These concentrations were selected for further studies because this synergistic effect provides significant protein release, yet many enzymes retain activity in the presence of these low levels of these two potential denaturants. ${ }^{11}$

\section{Recovery of enzyme activity} from recombinant $\mathrm{E}$. coli

Over $96 \%$ of the $\beta$-lactamase activity produced by $E$. coli $\mathrm{C} 600-1$ is found in the periplasm, and only trace amounts are found in the culture supernatant, making the foreign enzyme an excellent periplasmic marker. By contrast, $93 \%$ of the activity of the traditional cytoplasmic marker enzyme glucose 6-phosphate dehydrogenase (G6PDH) was found in the cytoplasm. Furthermore, neither of these two enzymes loses any activity in the presence of $0.2 \mathrm{M}$ guanidine and/or $0.5 \%$ Triton $\mathrm{X}-100$, either initially or over the course of a 48-h exposure, making them ideal markers for studying the release of cytoplasmic versus periplasmic enzymes of $E$. coli $\mathrm{C} 600-1$ by chemical permeabilization.

When $E$. coli cells are treated with either $0.5 \%$ Triton $\mathrm{X}-100$ or with $0.2 \mathrm{M}$ guanidine plus $0.5 \%$ Triton $\mathrm{X}-100$, both marker enzymes are released. In both cases, the percentage of G6PDH activity recovered is on the order of half as much as the percentage of overall protein recovered, and the percentage of $\beta$-lactamase activity recovered is nearly identical to the percentage of overall protein recovered. However, when $E$. coli cells are treated by $0.2 \mathrm{~m}$ guanidine alone, G6PDH is not detectable in the supernatant, but $\beta$-lactamase is quantitatively released (Figure 3 ). $\beta$-Lactamase recovery is $54 \%$ in the first hour and a half, and over $80 \%$ recovery is attained in only about $5 \mathrm{~h}$. In comparison, overall protein release by $0.2 \mathrm{M}$ guanidine is only about $4 \%$, resulting in significant purification of the recombinant, periplasmic enzyme. The specific activity of $\beta$-lactamase at $94 \%$ recovery is 40 times higher in the 0.2 M guanidine supernatant than in whole cell extract. Lysozyme/EDTA treatment of the cells resulted in only a 15 -fold purification of $\beta$-lactamase.

\section{Two-dimensional gel electrophoresis}

In order to generalize the results observed for the two marker enzymes, two-dimensional polyacrylamide gel electrophoresis (2D PAGE) studies were undertaken.

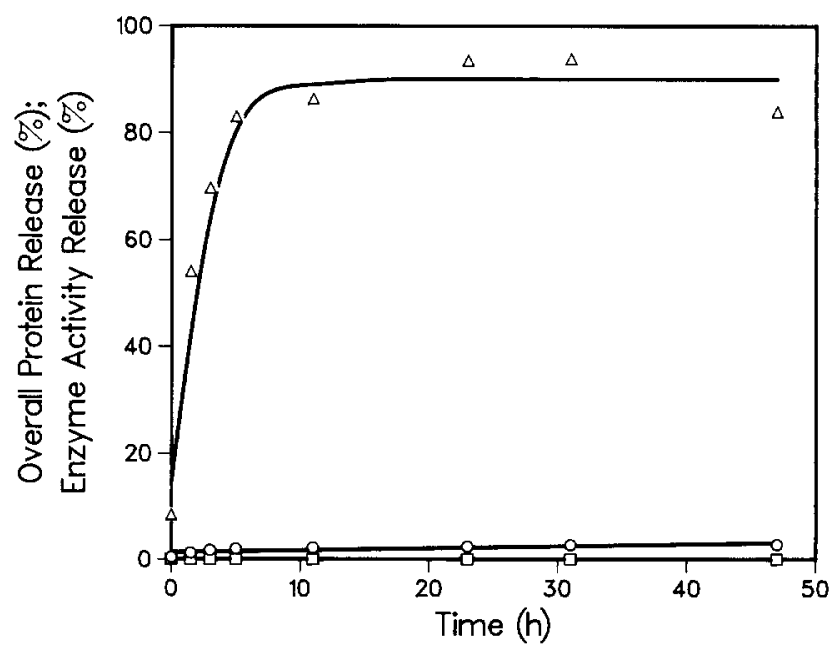

Figure 3 Overall protein release $(0)$, cytoplasmic maker enzyme Iglucose 6-phosphate dehydrogenase] activity release ( $\square$ ), and periplasmic marker enzyme [ $\beta$-lactamase] activity release $(\Delta)$ from $E$. coli $\mathrm{C} 600-1$ as a function of time during chemical permeabilization with $0.2 \mathrm{M}$ guanidine 
Periplasmic protein recovery: T. J. Naglak and H. Y. Wang
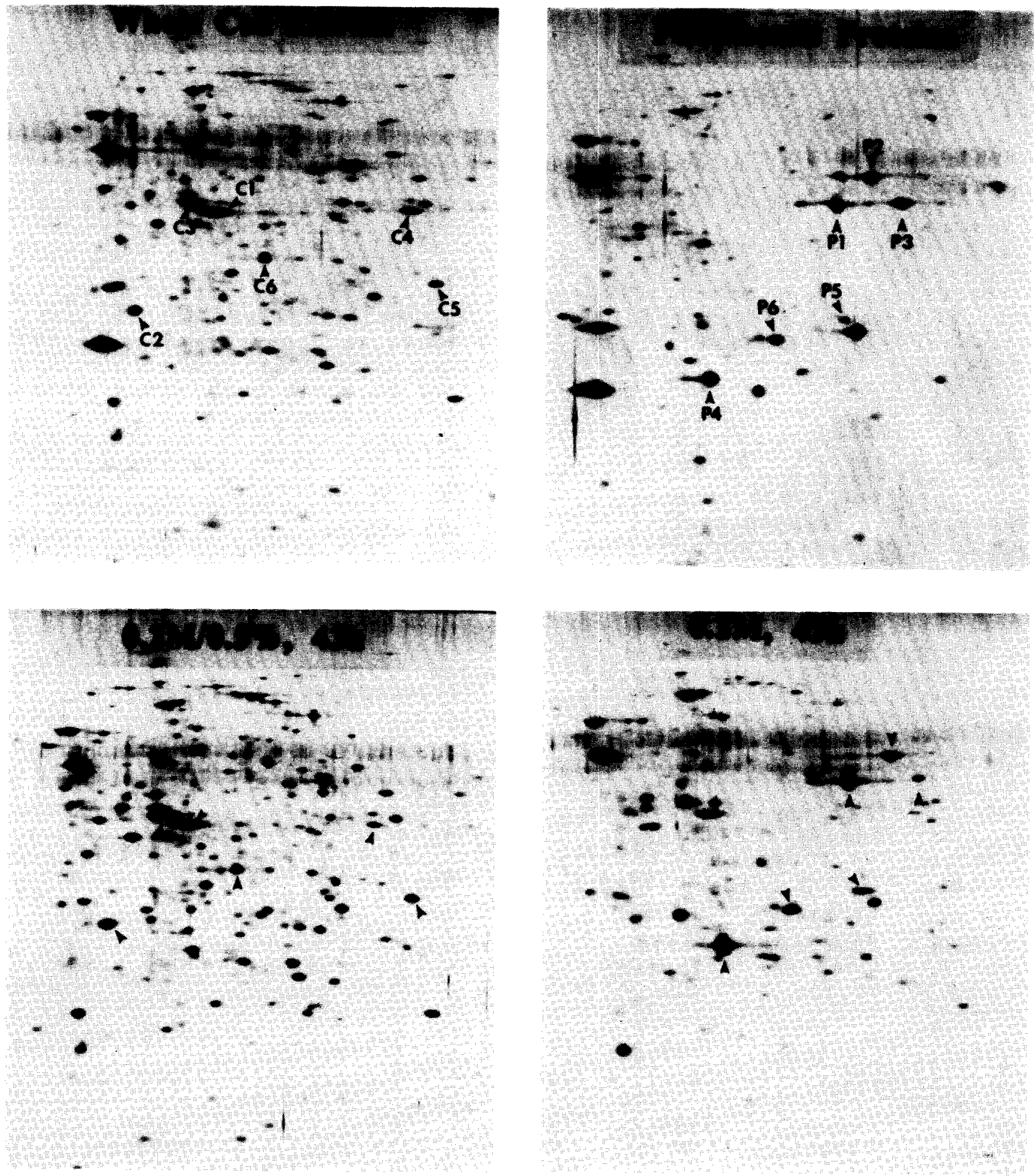

Figure 4 Two-dimensional electrophoresis gels of $E$. coli C600-1 proteins prepared in four different manners (clockwise from upper left: whole cell extract, periplasmic proteins purified by lysozyme/EDTA treatment, proteins released by treatment with $0.2 \mathrm{M}$ guanidine for $43 \mathrm{~h}$, proteins released by treatment with $0.2 \mathrm{M}$ guanidine plus $0.5 \%$ Triton $\mathrm{X}-100$ for $43 \mathrm{~h}$ ). Cytoplasmic markers $\mathrm{C} 1-\mathrm{C} 6$ are indicated on the two left-hand gels; periplasmic markers $\mathrm{P} 1-\mathrm{P} 6$ are indicated on the two right-hand gels

Using this technique, the entire intracellular protein profile can be visualized, and comparisons can be made between proteins released by chemical permeabilization and whole cell and periplasmic extracts.
Figure 4 consists of four 2D gels of $E$. coli proteins obtained in various manners. The top two gels show a whole cell extract prepared by sonication and a periplasmic extract prepared by lysozyme/EDTA 
treatment. ${ }^{23}$ The spot patterns are quite distinct, and many proteins are represented on only one of the two gels, serving as markers for the cytoplasm (lefthand gel) or periplasm (right-hand gel). Additionally, some spots are common to both gels, providing landmarks to allow for accurate gel to gel comparisons.

The lower two gels in Figure 4 represent proteins recovered by chemical permeabilization with either $0.2 \mathrm{M}$ guanidine and $0.5 \%$ Triton $\mathrm{X}-100$ (left-hand gel) or just 0.2 м guanidine (right-hand gel). Comparison with the upper two gels clearly demonstrates that the latter treatment is quite specific for periplasmic proteins, as anticipated by the enzyme activity recovery results. However, the protein pattern for the 0.2 $\mathrm{M}$ guanidine plus $0.5 \%$ Triton X-100 treatment closely resembles that for the whole cell extract, indicating no selectivity under these conditions.

Gels of supernatants from cells permeabilized with just $0.5 \%$ Triton $\mathrm{X}-100$ (not shown) qualitatively indicate that initially mostly periplasmic proteins are released. As the treatment progresses, however, cytoplasmic proteins are also released, in accordance with the observation of marker enzyme activity recovery from both periplasm and cytoplasm.

\section{Image analysis of $2 \mathrm{D}$ gels}

While the conclusion of selectivity by treatment with $0.2 \mathrm{M}$ guanidine is fairly obvious by merely observing the gels, analysis of selectivity as a function of extraction time with $0.5 \%$ Triton $\mathrm{X}-100$ requires quantification of relative protein concentrations using computeraided image analysis. Twelve marker protein spots, none necessarily corresponding to the marker enzymes quantified by activity, were selected, six for the cytoplasm and six for the periplasm (Figure 4). Spots were selected because they obviously correspond to one location or the other, but each also appears at least faintly on the opposing gel, allowing for accurate determination of their location on all sample gels.

Quantification of protein in a spot involves determining the integrated optical density (IOD) of the spot, a measure of its total darkness based on area as well as intensity. IOD varies linearly with the amount of protein in a spot on a silver-stained gel. ${ }^{27}$ Under the staining conditions and image analysis techniques used here, this linearity is observed, but the slope of the line relating IOD to amount varies from protein to protein. ${ }^{26}$ In this study, an identical amount of total protein was loaded onto each gel. Therefore, the ratio of the IOD of a given spot on a treatment sample gel to the IOD for the same spot on the whole cell extract gel represents its enhancement (value significantly greater than 1) or exclusion (value significantly less than 1) by the treatment. In that sense, the IOD ratio can be considered to be a purification factor.

Table $I$ is a compilation of IOD ratios for sample spots compared to whole cell extract for all 12 marker proteins in the three chemical permeabilization treatments involving $0.2 \mathrm{M}$ guanidine and/or $0.5 \%$ Triton $\mathrm{X}$ 100. The first column of Table 1 gives the same information for the periplasmic extract gel, providing a quantitative expression of the meaning of these marker spots.

For $0.2 \mathrm{M}$ guanidine, there is enhancement of periplasmic markers early in the treatment which tapers off slightly as small amounts of some cytoplasmic proteins are released slowly over the course of the permeabilization experiment. This selectivity is quite appreciable, especially early in the treatment, as indicated by IOD ratios for cytoplasmic markers significantly less than 1 and IOD ratios for periplasmic proteins exceeding those obtained by lysozyme/EDTA treatment. When $0.5 \%$ Triton $\mathrm{X}-100$ is added to $0.2 \mathrm{M}$ guanidine in a treatment, however, significant amounts of cytoplasmic proteins are released. The purification factors for periplasmic proteins are much lower, and the cyto-

Table 1 Ratio of integrated optical density (IOD) for $E$. coli C600-1 marker proteins on sample gels to whole cell extract gels for lysozyme/EDTA preparation of periplasmic proteins and for chemical permeabilization with guanidine and/or Triton X-100. Entries in bold face are statistically different from 1 at the $95 \%$ confidence level

\begin{tabular}{|c|c|c|c|c|c|c|c|}
\hline \multirow[b]{2}{*}{ Marker } & \multirow{2}{*}{$\begin{array}{c}\text { Periplasmic } \\
\text { extract }\end{array}$} & \multicolumn{2}{|c|}{$0.2 \mathrm{M}$ guanidine } & \multicolumn{2}{|c|}{$0.5 \%$ Triton $X-100$} & \multicolumn{2}{|c|}{$\begin{array}{c}0.2 \mathrm{M} \text { guanidine/ } \\
0.5 \% \text { Triton } X-100\end{array}$} \\
\hline & & $10 \mathrm{~h}$ & $43 h$ & $2 \mathrm{~h}$ & $43 h$ & $2 \mathrm{~h}$ & $43 \mathrm{~h}$ \\
\hline СYTO1 & 0.43 & 0.37 & 0.61 & 0.49 & 1.1 & 0.74 & 1.1 \\
\hline СYTO2 & 0.10 & 0.31 & 0.46 & 0.0 & 1.1 & 0.92 & 1.4 \\
\hline CYTO3 & 0.06 & 0.21 & 0.45 & 0.06 & 1.2 & 1.2 & 1.5 \\
\hline СYTO4 & 0.18 & 0.21 & 0.19 & 0.13 & 1.1 & 0.89 & 0.53 \\
\hline CYTO5 & 0.11 & 0.11 & 0.26 & 0.0 & 1.0 & 1.1 & 1.7 \\
\hline CYTO6 & 0.13 & 0.32 & 0.55 & 0.15 & 1.1 & 1.1 & 1.3 \\
\hline PERIP1 & 26 & 37 & 26 & 12 & 6.3 & 11 & 3.9 \\
\hline PERIP2 & 8.4 & 12 & 1.6 & 1.1 & 1.4 & 2.7 & 2.0 \\
\hline PERIP3 & 5.5 & 1.7 & 1.1 & 0.14 & 1.1 & 1.4 & 1.6 \\
\hline PERIP4 & 27 & 52 & 38 & 15 & 12 & 21 & 7.5 \\
\hline PERIP5 & 3.0 & 5.5 & 7.7 & 6.5 & 4.4 & 8.3 & 2.5 \\
\hline PERIP6 & 16 & 16 & 16 & 4.4 & 3.7 & 7.3 & 3.7 \\
\hline
\end{tabular}

IOD values for whole cell extract, periplasmic extract, and for all $43 \mathrm{~h}$ samples are average of 3 gels, $0.2 \mathrm{M}$ guanidine $10 \mathrm{~h}$ sample is average of 2 gels, and $0.5 \%$ Triton $X-100$ and $0.2 \mathrm{~m}$ guanidine plus $0.5 \%$ Triton $X-1002 \mathrm{~h}$ samples are based on 1 gel 


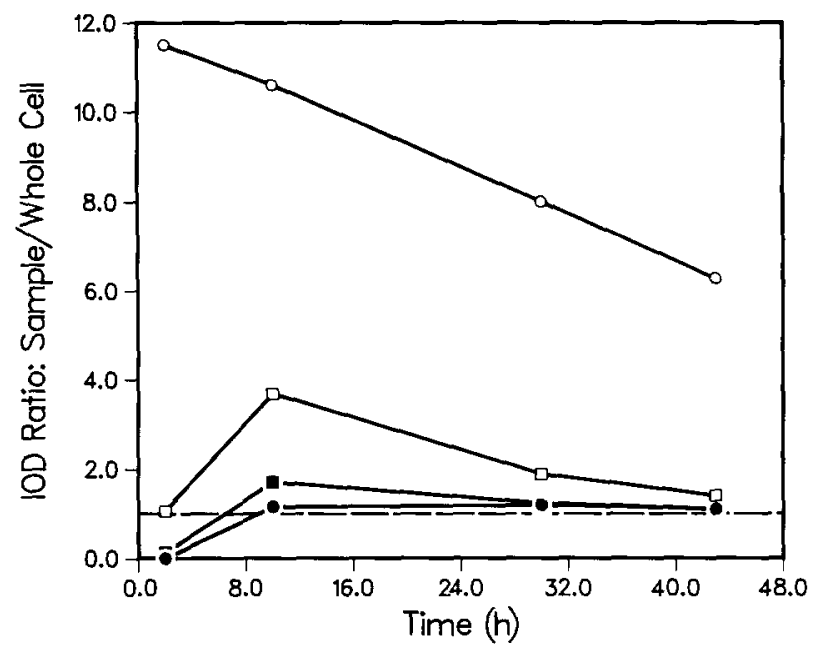

Figure 5 Time history of IOD ratio for two periplasmic and two cytoplasmic marker proteins during chemical permeabilization of $E$. coli $600-1$ by $0.5 \%$ Triton $X-100$. The markers are, as referenced in Figure 4, PI (O), P2 ( $\square), \mathrm{C} 2(\mathrm{O})$, and C4 (口)

plasmic markers display IOD ratios near 1 , indicating a loss of selectivity.

For $0.5 \%$ Triton $\mathrm{X}-100$ used alone, selectivity is observed, but it is related to the time history of the treatment. Initial samples show very little release of cytoplasmic proteins. Over the course of the treatment, however, these proteins are released, and their IOD ratios tend toward 1 . Consequently, the purification factors for periplasmic proteins drop later in the treatment, the net result being no selectivity after a few hours of exposure to $0.5 \%$ Triton $\mathrm{X}-100$. It is also interesting to note that the purification factors for the periplasmic proteins do not all peak with the first sample; half of the periplasmic markers display maxima in their IOD ratios at the 10-h sample. Figure 5 summarizes these results graphically for four of the marker spots, showing their complete time history over the course of the treatment. Spots PERIP1 and PERIP2 display examples of the two different profiles observed for periplasmic markers, namely peaking either in the 2 -h sample or in the 10 -h sample.

\section{Discussion}

\section{Image analysis}

Interpretation of data from $2 \mathrm{D}$ gels is a difficult task, even with the aid of image analysis techniques. In general, spot patterns on gels are very reproducible, but variations in the amount of protein entering a gel for the same loading and in the staining itself can result in variations in spot intensity. Therefore, it is necessary to consider the reproducibility of IOD measurements for the same spot on replicate gels to determine whether variations from unity in the IOD ratio are statistically significant.

For the gels in this study, that reproducibility was quite good. For example, for the marker CYTO1, the average IOD on three whole cell extract gels was 387 (arbitrary units), with a standard deviation of 34; the average for the same spot on three periplasmic extract gels was 168 , with a standard deviation of 10 . Similarly, marker PERIP1 has an average IOD of 727 , standard deviation 76 , on three periplasm gels, and an average IOD of 27.6 , standard deviation 0.4 , on three whole cell gels. The standard deviation of the image analysis measurement for quantifying a protein on replicate gels of the same sample for most of the marker spots is less than of $10 \%$ of the mean, and no marker spot exhibited a standard deviation any higher than $25 \%$ of the mean.

For the $0.2 \mathrm{M}$ guanidine treatment, values of the IOD ratio for all the cytoplasmic markers are significantly less than 1, and values for five of the six periplasmic markers are significantly greater than 1, at the $95 \%$ confidence level. Thus, the qualitative conclusion of selectivity in the $0.2 \mathrm{M}$ guanidine treatment based on comparing the spot patterns of the gels in Figure 4 is easily quantified by the image analysis data in Table 1.

It is also clear from Table $I$ and Figure 5 that the $0.5 \%$ Triton $\mathrm{X}-100$ treatment starts out displaying selectivity for the periplasm but ends up losing this specificity as the IOD ratios for cytoplasmic markers generally start near zero but all end up statistically equivalent to 1. Though the IOD ratios for some of the periplasmic markers are still significantly higher than 1 even at the end of the treatment, all display a decrease as time progresses past the 10 -h sample.

The $0.2 \mathrm{M}$ guanidine plus $0.5 \%$ Triton $\mathrm{X}-100$ treatment shows some enhancement of periplasmic proteins initially, but the selectivity is not high, as demonstrated by IOD ratios generally near 1 for the cytoplasmic markers. Of course, as this treatment ends up extracting over $50 \%$ of intracellular protein, a lack of selectivity is to be expected.

It is worth noting that the $\mathbf{1 2}$ markers were selected on the basis of appearing on both whole cell and periplasm gels in order that there be no ambiguity in locating them on any sample gel. In addition to markers such as those selected, there are numerous spots which appear only on whole cell gels or on periplasm gels. Of course, cytoplasmic proteins should not appear on periplasmic extract gels, but it should be noted that a periplasmic protein will not appear on the whole cell gel if its concentration in whole cell extract is below the detection limit of the staining protocol. Many such qualitative periplasmic markers appear only on sample gels for which periplasmic selectivity is contended. Similarly, many qualitative cytoplasmic markers support the contention that addition of Triton X-100 to a treatment is necessary for release of cytoplasmic proteins (see Figure 4).

\section{Selectivity and the mechanism of chemical permeabilization}

The underlying phenomena resulting in the complex wave-like variation of protein recovery with guanidine concentration shown in Figure $l$ have been studied by 
transmission electron microscopy. The explanation for this wave-like response involves competition between factors involving protein release and protein aggregation and will be presented in a forthcoming paper. ${ }^{18}$ Of interest here is the observation from electron micrographs that guanidine attacks the outer membrane while Triton X-100 solubilizes the inner membrane. This distinction in the mode of action of the two chemical permeabilization agents should allow for selectivity in protein release based on intracellular location under different treatment conditions. The present work confirms this possibility. Marker protein release studies show that guanidine acting alone extracts mostly periplasmic proteins, further justifying the contention that guanidine's point of action is the outer membrane.

Treatment of $E$. coli cells by Triton X-100, in the presence or absence of guanidine, results in release of cytoplasmic proteins as well as periplasmic proteins, demonstrating that Triton X-100 can affect the inner membrane. However, it is important to note that in the absence of guanidine, $0.5 \%$ Triton X-100 extracts very little overall protein, only on the order of $10 \%$. Addition of guanidine with Triton X-100 can extract over 50\% of intracellular protein, indicating that Triton X-100 alone is ineffective at disrupting the cells, in accordance with the known detergent resistance of the outer membrane of Gram-negative bacteria. ${ }^{17,28}$ The combination of the two agents, however, exerts a synergistic effect whereby guanidine disrupts the outer membrane, allowing Triton X-100 to solubilize the inner membrane more effectively. ${ }^{18}$

\section{Implications for protein production and recovery}

This synergistic effect is observed at low concentrations for the two treatment chemicals. Many enzymes retain activity in the presence of $0.2 \mathrm{M}$ guanidine and/ or $0.5 \%$ Triton $\mathrm{X}-100 .{ }^{11}$ This is true for the two marker enzymes studied here, $\beta$-lactamase and glucose 6-phosphate dehydrogenase. The current work demonstrates that chemical permeabilization can be used to recover active enzymes from either the periplasm or the cytoplasm of E. coli.

The selectivity observed in treating $E$. coli cells with guanidine alone provides the potential for substantial purification of periplasmic proteins in the cell disruption stage of an overall protein production process. In this instance, recombinant $\beta$-lactamase was recovered at $94 \%$ yield with 40 -fold enhancement of specific activity. Such high purification in this early stage of the production process could help alleviate some of the problems traditionally associated with recovery of intracellular recombinant products, such as low expression or the need to solubilize cytoplasmic inclusion bodies. Genetic engineering advances currently allow for periplasmic expression of foreign proteins. Such expression may have advantages beyond ease in recovery. In the case of human growth hormone, the reducing conditions of the periplasm provide the proper environment for correct disulfide bond formation, normally quite difficult to accomplish with cytoplasmic expression in this procaryotic host. ${ }^{1}$

Chemical permeabilization by guanidine compares favorably to traditional means of purifying periplasmic proteins. Although the gels presented were of parallel 43-h samples, it should be noted that the time required to obtain qualitative release of periplasmic proteins with high selectivity is on the order of $2-5 \mathrm{~h}$, as shown by marker enzyme assays in Figure 3, as well as by further gels not shown here. This is comparable to the length of time required to carry out an osmotic shock procedure or a lysozyme/EDTA digestion when considering the additional sugar solution equilibration step inherent in these two methods. Osmotic shock treatment also requires an additional centrifugation step, complicating the recovery scheme and incurring additional capital expense, and can release more contaminating proteins from the cytoplasm (2D gels not shown). Furthermore, although results vary from protein to protein, treatment by guanidine generally provides higher purification of periplasmic proteins than disruption of the outer wall by lysozyme/EDTA (compare the first two columns of Table 1 for the six periplasmic markers) and is two orders of magnitude less expensive. Thus, the present work demonstrates that chemical permeabilization is a viable technique to consider when attempting to recover and purify active native or recombinant proteins from E. coli.

\section{Acknowledgements}

E. coli $\mathrm{C} 600-1$ was kindly provided by Professor Tadayuki Imanaka of Osaka University. The support of the National Science Foundation, Grant No. ECE8603976, is gratefully acknowledged.

\section{References}

1 Hsiung, H. M., Maynew, N. G. and Becker, G. W. Bio/Technology 1986, 4, 991-995

2 Matteucci, M. and Lipetsky, H. Bio/Technology 1986, 4, 51-55

3 Gray, G. L., Baldridge, J. S., McKeown, K. S., Heyneker, H. L. and Chang, C. N. Gene 1985, 39, 247-254

4 Emerick, A. W., Bertolani, B. L., Ben-Bassat, A., White, T. J. and Konrad, M. W. Bio/Technology 1984, 2, 165-168

5 Talmadge, K., StahI, S. and Gilbert, W. Proc. Natl. Acad. Sci. USA $1980,77,3369-3373$

6 Talmadge, K., Kaufman, J. and Gilbert, W. Proc. Natl. Acad. Sci. USA 1980, 77, 3988-3992

7 Bayer, M. E. J. Bacteriol. 1967, 93, 1104-1112

8 Wickner, R. B. and Hurwitz, J. Biochem. Biophys. Res. Commun. 1972, 47, 202-211

9 Neu, H. C. and Heppel, L. A. Proc. Natl. Acad. Sci. USA $1964,51,1267-1274$

10 DePamphilis, M. L. and Adler, J. J. Bacteriol. 1971, 105, 376-383

11 Hettwer, D. and Wang, H. Biotech. Bioeng. 1989, 33, 886-895

12 Hammes, G. G. and Swann, J. Biochemistry 1967, 6, 1591-1596

13 Hatefi, Y. and Hanstein, W. G. Methods Enzymol. 1974, 31, $770-790$

14 Moldow, C., Robertson, J. and Rothfield, L. J. Membrane Biol. 1972, 10, 137-152 
15 Helenius, A. and Simons, K. Biochim. Biophy. Acta 1975, 415, 29-79

16 Schnaitman, C. A. J. Bacteriol. 1971, 108, 545-552

17 Nixdorff, K., Gmeiner, J. and Martin, H. H. Biochim. Biophys. Acta 1978, 510, 87-98

18 Hettwer, D. and Wang, H. Y. (submitted for publication)

19 Imanaka, T., Tanaka, T., Tsunekawa, H. and Aiba, S. J. Bacteriol. 1981, 147, 776-786

20 Bradford, M. Anal. Biochem. 1976, 72, 248-254

21 Sargent, M. G. J. Bacteriol. 1968, 95, 1493-1495

22 Enzymes and Related Biochemicals Worthington Diagnostic Systems, Inc., Freehold, NJ, 1982, pp. 85-86
23 DePamphilis, M. L. and Adler, J. J. Bacteriol. 1971, 105, 376-383

24 Phillips, T. A. DNA Protein Eng. Techn. 1988, 1, 5-9

25 Damerval, C., le Guilloux, M., Blaisonneau, J. and de Vienne, D. Electrophoresis $1987,8,158-159$

26 Dykstra, K. H. and Wang, H. Y. Ann. NY Acad. Sci. 1987, 506, $511-522$

27 Merril, C. R., Goldman, D. G. and Van Keuren, M. L. Electrophoresis $1982,3,17-23$

28 Koch, A. L. and Schaechter, M. in Biology of Industrial Microorganisms (Demain, A. L. and Solomon, N. A., eds.) Benjamin/Cummings Publishing Company, London, 1985, pp. 1-25 